Vol. 3 No. 1

Juni 2021

e- ISSN $2685-0559$

p- ISSN $2684-673 X$

\title{
TEMA DALAM NOVEL-NOVEL PERIODE BALAI PUSTAKA
}

\author{
Devi Cintia Kasimbara ${ }^{1}$ \\ Universitas PGRI Madiun (UNIPMA), Madiun, Indonesia) \\ devi.ck@unipma.ac.id ${ }^{1}$ \\ Wahyuningsih $^{2}$ \\ Universitas PGRI Madiun (UNIPMA), Madiun, Indonesia) \\ wahyuningsih@unipma.ac.id ${ }^{1}$ \\ Kodrat Eko Putro Setiawan ${ }^{3}$ \\ Universitas PGRI Madiun (UNIPMA), Madiun, Indonesia) \\ kodrat.ep@unipma.ac.id ${ }^{1}$
}

\begin{abstract}
Balai Pustaka is the initial period of the emergence of modern Indonesian literature, so it is necessary to know more about the novels that have become milestones in the history of the emergence of modern Indonesian literature. During this period, many novels emerged with stories that had various similarities. This prompted the writer to find out what themes dominated the novels published in this period. In this study, the authors took six novel samples, namely Azab and Sengsara by Merari Siregar, Sitti Nurbaya by Marah Rusli, Salah Asuhan by Abdoel Moeis, Looking for the Thief of Virgins by Suman Hs., and Dian Yang Takdir Alisjahbana by S. Takdir Alisjahbana. The theory Robert Stanton is used as an analytical knife. In this theory, Stanton focused more on how to identify the theme of a literary work, where the theme is an aspect of the story that is parallel to the 'meaning' in human experience; something that makes an experience so memorable. The results of this study could be seen that the themes raised in the novels of the Balai Pustaka period have similarities, namely traditional issues, forced marriages, and the conflict between the old and young groups so that these novels have similarities in the issues raised.
\end{abstract}

Keywords: themes, novels, Balai Pustaka

\section{PENDAHULUAN}

Seiring perkembangan

zaman, analisis karya sastra secara poststruktural menjadi lebih diminati oleh peneliti dibandingkan dengan analisis secara struktural karena lebih dianggap sebagai suatu 
pendekatan yang baru dan lebih luas cakupannya. Berbeda dengan pendekatan struktural yang lebih memfokuskan pada karya sastra sebagai objek analisis. Ratna (2011: 88) mengungkapkan bahwa dalam menganalisis sebuah karya sastra dengan menggunakan pendekatan apapun selalu didahului dengan menganalisis struktur karya itu sendiri. Strukturalisme dalam penelitian sastra dipandang sebagai suatu teori yang telah berhasil memasuki hampir seluruh bidang kehidupan manusia karena strukturalisme dianggap sebagai salah satu teori modern yang berhasil membawa manusia pada pemahaman yang maksimal. Berdasarkan hal tersebut, penulis akan mengkaji karya sastra berdasarkan pendekatan strukural, mengingat penelitian yang memfokuskan kepada karya sastra sebagai objek material sudah jarang dilakukan padahal memahami sastra secara strukural merupakan sesuatu yang sangat penting.

Dalam penelitian ini penulis akan mengkaji novel-novel Indonesia pada periode Balai Pustaka. Periode ini dipilih dengan alasan bahwa ini adalah periode awal munculnya sastra Indonesia modern sehingga perlu kiranya mengetahui lebih lanjut mengenai novel-novel yang menjadi tonggak sejarah munculnya karya sastra Indonesia modern. Selain itu, jika diamati novel-novel dalam periode Balai Pustaka memiliki kesamaan. Dalam penelitian ini, penulis akan mengkaji tema dalam novel-novel Indonesia pada periode Balai Pustaka.
Pengkajian terhadap tema dilakukan karena penulis ingin melihat dan membuktikan tema-tema yang mendominasi novel-novel pada periode ini, melihat pada periode ini banyak novel-novel yang muncul dengan mengangkat persoalan kawin paksa dan pertentangan antara golongan tua dengan golongan muda.

Oleh karena itu, penulis menggunakan teori tema dari Robert Stanton untuk menjawab masalah tersebut. Dipilihnya teori Stanton ini dengan alasan teori ini lebih menekankan bagaimana cara mengidentifikasi tema dalam suatu karya sastra sehingga dengan digunakannya teori ini, penulis akan lebih mudah dalam menemukan tema-tema dalam novel-novel periode Balai Pustaka.

\section{LANDASAN TEORI}

Kesusastraan suatu bangsa selalu mengalami perkembangan dari waktu-waktu, begitu juga dengan kesusastraan Indonesia. Dengan demikian sejarah sastra itu tak lain dari rangkaian atau jajaran periode-periode sastra (Pradopo, 2013: 2). Periode menurut Wellek dan Warren (2014: 330) merupakan bagian waktu yang didominasi oleh sistem norma, standar konvensi sastra, yang dapat ditelusuri penyebaran, diversifikasi, integrasi, dan kepunahannya. Lebih lanjut Wellek dan Warren menjelaskan bahwa rangkaian periode sastra itu jangan dibayangkan seperti balokbalok batu yang dijajarkan secara berurutan, melainkan hendaklah 
Vol. 3 No. 1

Juni 2021

e- ISSN 2685 - 0559

p- ISSN 2684 - 673X

dilihat bahwa periode sastra itu saling bertumpang tindih (2014: 330331). Tokoh-tokoh sastra Indonesia yang membuat perodisasi, di antaranya H.B. Jassin, Boejoeng Saleh, Nugroho Notosusanto, Bakri Siregar, Ajib Rosidi, dan Rachmat Djoko Pradopo. Periodisasi tokohtokoh tersebut secara umum menunjukkan kesamaan, perbedaan hanya pada batas-batas waktu periode dan ciri-cirinya. Dalam penelitian ini penulis menggunakan model periodisasi Rachmat Djoko Pradopo. Dalam bukunya Beberapa Teori Sastra, Metode Kritik, dan Penerapannya Pradopo mengungkapkan bahwa ia menggunakan periodisasi tokohtokoh di atas sebagai ancar-ancar dan menggunakan konsep periodisasi Renne Wellek dan Austin Warren yang telah diungkapkan di atas. Menurut Pradopo (2013: 18) gambaran sesungguhnya periodeperiode sejarah sastra Indonesia bertumpang tindih sebagai berikut.

1. Periode Balai Pustaka: 1920-1940;

2. Periode Pujangga Baru: 19301945;

3. Periode Angkatan 45: 1940-1955;

4. Periode Angkatan 50: 1950-1970;

5. Periode Angkatan 70: 1965sekarang (1984)

Dalam periodisasi terlihat adanya tahun-tahun yang bulat yang digunakan untuk mempermudah pengingatan dan pemahaman dalam studi sastra. Lagi pula lahirnya, tersebarnya, dan terintegrasinya suatu periode sastra atau angkatan sastra pada umumnya kurang jelas batas-batas waktunya. Jadi, tahuntahun bulat itu sebagai ancar-ancar timbulnya, tersebarnya, terintegrasi, dan lenyapnya suatu periode atau angkatan sastra (Pradopo, 2013: 18). Penelitian ini berfokus pada novelnovel dalam periode Balai Pustaka saja, yang mana menurut Pradopo lahirnya periode Balai Pustaka sekitar tahun 1920 dan melemahnya kekuatan atau lenyapnya di sekitar tahun 1940. Waktu terintegrasinya kekuatan (dan ciri-ciri) sastra Balai Pustaka antara 1925-1935, sedangkan karya sastra dalam periode Pujangga Baru pada tahun 1930 sudah mulai menunjukkan ciriciri periode atau angkatan yang kuat, namun masa terintegrasinya kekuatan pada tahun 1933-1940.

Berdasarkan hal tersebut, penelitian ini membahas novel-novel periode Balai Pustaka dalam rentang waktu tahun 1920-1935 untuk melihat bagaimana tema-tema yang dominan dalam periode awal sejarah sastra Indonesia. Dipilihnya periode Balai Pustaka dalam penelitian ini karena pada periode ini banyak bermunculan novel-novel yang nenandai awal berkiprahnya Sastra Indonesia. Adapun ciri-ciri ekstra estetik karya sastra dalam periode Balai Pustaka menurut Pradopo (2013: 23-24), yaitu (1) bermasalah adat, terutama masalah adat kawin paksa, permaduan, dan sebagainya; (2) pertentangan paham antara kaum tua dengan kaum muda. Kaum tua mempertahankan adat lama, sedang kaum muda menghendaki kemajuan menurut paham kehidupan modern; (3) latar cerita pada umumnya latar daerah, pedesaan, dan kehidupan daerah; (4) cerita bermain di zaman 
Vol. 3 No. 1

Juni 2021

e- ISSN 2685 - 0559

p- ISSN 2684 - 673X

sekarang, bukan di tempat dan zaman antah-berantah; dan (5) citacita kebangsaan belum dipermasalahkan, masalah masih bersifat kedaerahan.

Penelitian ini menggunakan teori tema dari Robert Stanton. Teori tema yang dikemukakan oleh Stanton tidak mengklasifikasikan tema ke dalam beberapa jenis, namun Stanton lebih menitikberatkan kepada cara mengidentifikasi tema sebuah karya sastra. Tema menurut Stanton (2012: 36) merupakan aspek cerita yang sejajar dengan 'makna' dalam pengalaman manusia; sesuatu yang menjadikan suatu pengalaman begitu diingat. Sama seperti makna pengalaman manusia, tema menyorot dan mengacu pada aspekaspek kehidupan sehingga nantinya akan ada nilai-nilai tertentu yang melingkupi cerita. Tema membuat cerita lebih terfokus, menyatu, mengerucut, dan berdampak. Bagian awal dan akhir cerita akan menjadi pas, sesuai, dan memuaskan berkat keberadaan tema. Tema merupakan elemen yang relevan dengan setiap peristiwa dan detail sebuah cerita.

Stanton (212:

menjelaskan bahwa tema dapat diibaratkan 'maksud' dalam sebuah gurauan, tetapi tetap mengalami kesulitan ketika diminta untuk menjelaskannya. 'Maksud' adalah hal yang membuat sebuah gurauan jadi lucu; dalam konteks ini, 'maksud' merujuk pada fungsi dan bukan definisi. Kita sudah paham betul bahwa 'tema' sebuah cerita terletak pada 'makna'-nya. Akan tetapi, makna dalam sebuah karya sastra teramat taksa, akan sulit mengetahui makna mana yang lebih penting daripada makna lainnya sehingga Stanton (2012: 41) menyimpulkan bahwa tema adalah makna yang dapat merangkum semua elemen dalam cerita dengan cara yang paling sederhana.

Cara paling efektif untuk mengenali tema sebuah karya menurut Stanton (2012: 42-43) adalah dengan mengamati secara teliti setiap konflik yang ada di dalamnya. Kedua hal ini berhubungan sangat erat dan konflik utama biasanya mengandung sesuatu yang sangat berguna jika benar-benar dirunut. Lebih lanjut Stanton (2012: 44-45) mengungkapkan bahwa tema hendaknya memenuhi kriteriakriteria sebagai berikut.

1. Interpretasi yang baik hendaknya selalu mempertimbangkan berbagai detail menonjol dalam sebuah cerita;

2. Interpretasi yang baik hendaknya tidak terpengaruh oleh berbagai detail cerita yang saling berkontradiksi;

3. Interpretasi yang baik hendaknya tidak sepenuhnya bergantung pada bukti-bukti yang tidak secara jelas diutarakan (hanya disebut secara implisist);

4. Terakhir, interpretasi yang dihasilkan hendaknya diujarkan secara jelas oleh cerita bersangkutan.

Oleh karena itu, harus segera diingat bahwa proses mencari tema sama saja dengan bertanya pada diri kita sendiri, "Mengapa pengarang 
Vol. 3 No. 1

Juni 2021

e- ISSN 2685 - 0559

menulis cerita ini? Mengapa cerita tersebut dituliskan?" (Stanton, 2012: 46).

\section{METODE PENELITIAN}

Penelitian ini menggunakan metode penelitian kualitatif dengan pendekatan strukturalisme dan dianalisis dengan teori tema dari Robert Stanton. Sumber data penelitian ini adalah novel-novel yang terbit pada masa periode Balai Pustaka. Tidak semua novel dipakai dalam penelitian ini, penelitian ini hanya mengambil enam sampel novel, yaitu Azab dan Sengsara (1921) karya Merari Siregar, Sitti Nurbaya (1922) karya Marah Rusli, Salah Asuhan (1928) karya Abdoel Moeis, Mencari Pencuri Anak Perawan (1931) karya Suman Hs., dan Dian yang Tak Kunjung Padam (1932) karya S. Takdir Alisjahbana. Untuk pengumpulan data, penelitian ini menggunakan metode simak, yaitu dengan menyimak satuansatuan linguistik yang signifikan yang ada di dalam teks enam novel tersebut. Teknik analisis yang dipakai adalah analisis konten. Dalam penelitian ini, analisis data dilakukan dengan mengindentifikasi tema-tema yang ada dalam keenam novel periode Balai Pustaka dengan cara mengamati secara teliti setiap konflik yang ada dalam karya. Tema adalah makna yang dapat merangkum semua elemen dalam cerita dengan cara yang paling sederhana. Tema pun harus dapat dibuktikan dalam teks novel yang bersangkutan. Proses mencari tema sama saja dengan bertanya pada diri kita sendiri mengapa pengarang menulis cerita ini? Mengapa cerita tersebut dituliskan?.

\section{HASIL DAN PEMBAHASAN}

Dalam penelitian ini, penulis menggunakan lima sampel novel, yaitu Azab dan Sengsara (1921) karya Merari Siregar, Sitti Nurbaya (1922) karya Marah Rusli, Salah Asuhan (1928) karya Abdoel Moeis, Mencari Pencuri Anak Perawan (1931) karya Suman Hs., dan Dian yang Tak Kunjung Padam (1932) karya S. Takdir Alisjahbana.

Mengidentifikasi tema dalam suatu karya sastra bukanlah persoalan yang mudah. Tema hanya dapat diperoleh setelah kita selesai membaca suatu karya. Untuk mengidentifikasi sebuah tema, kita dapat mengamati konflik yang ada pada karya sastra. Pertama, novel Azab dan Sengsara karya Merari Siregar. Novel yang terbit pada tahun 1921 ini merupakan novel pertama dalam periode Balai Pustaka. Novel ini menceritakan mengenai dua orang muda mudi yang cintanya harus kandas karena perbedaan derajat. Konflik dalam novel ini dapat dilihat pada permulaan cerita bahwa nasib buruk yang menimpa Mariamin bermula dari sang ibu yang dipaksa untuk menikah dengan sang ayah tanpa diberi kesempatan untuk mengenal. Sang ibu dipaksa menikah dengan seorang lelaki yang keji dan buruk perilakunya hanya karena kebangsaan dan kekayaan lelaki itu. Setelah menikah, akhirnya kehidupan mereka tidak bahagia 
Vol. 3 No. 1

Juni 2021

e- ISSN 2685 - 0559

p- ISSN 2684 - 673X

hingga mereka jatuh miskin karena ulah sang suami. Hal ini sama halnnya dengan Mariamin, setelah hubungan cintanya yang kandas dengan Aminuddin karena ayah Aminuddin yang tidak merestui karena Mariamin berasal dari keluarga miskin, Mariamin dipaksa ibunya untuk segera menikah dengan seorang lelaki yang tidak dikenalnya. Alhasil pernikahan itu akhirnya kandas karena suami Mariamin mengidap penyakit kelamin yang menular dan suka menyiksanya. Novel ini berakhir tragis karena Mariamin akhirnya meninggal dalam kesengsaraan yang melingkupinya, seperti terlihat pada kutipan berikut.

"Maka di sanalah air mata itu kering karena suatu pun tak ada lagi yang menyusahkan hati. Azab dan Sengsara dunia ini telah tinggal di atas bumi, berkubur dengan jazad badan yang kasar itu".

(Siregar, 2013: 163)

Secara keseluruhan dapat disimpulkan bahwa tema yang diangkat dalam novel Azab dan Sengsara ini adalah pemaksaan kehendak golongan tua kepada golongan muda dalam hal pemilihan jodoh tanpa memberi kesempatan golongan muda untuk memilih dan mengenal pasangannya akan membuat ketidakbahagiaan dan kesengsaraan hidup golongan muda.

Novel berikutnya adalah Sitti Nurbaya (1922) karya Marah Rusli. Dalam novel ini konflik terjadi antara
Sitti Nurbaya, Samsulbahri, dan Datuk Meringgih yang mana Datuk Meringgih merupakan tokoh yang menggagalkan tali percintaan Sitti Nurbaya dan Samsulbahri. Konflik bermula saat ayah Sitti Nurbaya (Baginda Sulaiman) jatuh miskin karena ulah Datuk Meringgih yang tidak suka melihat kesuksesan perdagangan Baginda Sulaiman. Baginda Sulaiman yang tidak menyadari kejahatan Datuk Meringgih akhirnya meminjam uang kepada Datuk Meringgih. Karena tidak bisa melunasi hutanghutangnya, akhirnya Sitti Nurbaya menyerahkan diri kepada Datuk Meringgih karena tidak mau ayahnya dipenjara. Singkat cerita, konflik terus terjadi antara ketiga tokoh ini, sampai akhirnya Sitti Nurbaya meninggal karena diracun oleh orang suruhan Datuk Meringgih, dan 10 tahun kemudian Samsulbahri dan Datuk Meringgih bertemu di medan perang. Samsulbahri mewakili pemerintah kolonial, sedangkan Datuk Meringgih mewaliki pribumi, yang kemudian berakhir dengan meninggalnya kedua tokoh. Berikut ini pernyataan Samsulbahri kepada Datuk Meringgih saat mereka bertemu di medan perang.

"Sepuluh tahun lamanya aku menanggung sengsara dan dukacita yang tiada terderita, sepuluh tahun pula aku menaruh dendam dalam hatiku kepadamu. Sekarang barulah disampaikan Tuhan maksud itu; sekarang barulah dapat aku menuntutkan bela 
Vol. 3 No. 1

Juni 2021

e- ISSN 2685 - 0559

p- ISSN $2684-673 X$

sekalian orang yang telah engkau aniaya, hai penjahat yang sebesar-besarnya! Karena kekayaanmu, menjadikan engkau sombong dan angkuh serta tekebur kepada Tuhan, yang telah memberimu kekayaan itu".

(Rusli, 2013: 245)

Berdasarkan konflik tersebut dapat disimpulkan bahwa tema dalam novel ini adalah percintaan yang kandas karena tekanan masyarakat tradisional yang membuat sang tokoh akhirnya membalaskan dendam dengan cara bergabung dengan pihak kolonial. Tekanan dari masyarakat tradisional ini antara lain tekanan dari ayah Samsulbahri yang merasa malu atas tuduhan yang ditimpakan kepada anaknya bahwa anaknya telah menggoda istri orang lain, yang tak lain adalah Datuk Meringgih, yang kemudian sang ayah mengusir Samsulbahri. Tekanan kedua berasal dari Datuk Meringgih. Tokoh ini merupakan tokoh yang menyulut terjadinya konflik hingga akhirnya dengan akal liciknya membuat Sitti Nurbaya terbunuh.

Novel ketiga yaitu Salah Asuhan (1928) karya Abdoel Moeis. Konflik dalam novel ini sebenarnya timbul karena orangtua yang salah dalam mengasuh dan mendidik anaknya. Sejak kecil Hanafi telah mendapatkan pendidikan barat dan dititipkan pada keluarga Belanda sehingga sikapnya menjadi kebaratbaratan. Pendidikan dan pergaulannya yang serba Belanda membuatnya kehilangan jati dirinya, terlebih saat dia jatuh cinta dengan Corrie, seorang gadis Indo-Perancis. Hanafi juga menolak perjodohannya dengan Rapiah meskipun akhirnya dengan terpaksa menerima perjodohan itu karena ibunya yang berutang budi kepada ayah Rapiah. Meskipun telah mempunyai istri, Hanafi tetap mencintai Corrie. Bahkan dia rela meninggalkan istri dan anaknya dan mengurus surat mengakuan bahwa dia memperoleh hak-hak yang dimiliki orang Eropa. Namun, hal tersebut tidak membuat Hanafi bahagia karena pada akhirnya orang-orang Eropa tetap mengganggap Hanafi bukanlah bagian dari mereka. Pernikahnanya pun dengan Corrie tidak bahagia karena perbedaan budaya dan adat istiadat, sebagaimana dikatakan oleh Corrie dalam suratnya kepada Hanafi berikut ini.

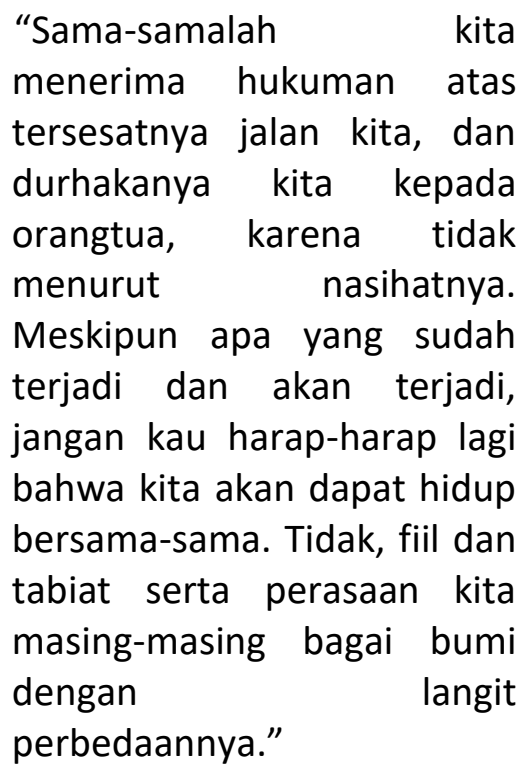

(Moeis, 2013: 218)

Berdasarkan konflik tersebut dapat disimpulkan bahwa tema dalam novel ini adalah akibat yang 
Vol. 3 No. 1

Juni 2021

e- ISSN 2685 - 0559

p- ISSN 2684 - 673X

diterima oleh seseorang yang kehilangan jati diri kebangsaannya akibat orangtua yang salah dalam mengasuh. Kata akibat digunakan oleh penulis karena hilangnya jati diri kebangsaan tokoh Hanafi telah membuatnya menerima sangsi alam, yaitu tidak diterima oleh bangsa sendiri dan juga bangsa Eropa.

Novel keempat yaitu Mencari Pencuri Anak Perawan (1931) karya Suman Hs. Novel ini hampir menyerupai novel detektif karena unsur kejutannya. Konflik dalam novel ini beraawal ketika Sir Joon yang telah bertunangan dengan Nona terputus tali pertunangannya karena ayah Nona menerima lamaran dari lelaki lain yang disebabkan oleh tergiurnya dengan mas kawin yang diajukan yaitu 600 dolar. Sir Joon kemudian mengatur siasat untuk menggagalkan pernikahan Nona dengan Tairoo dengan cara menculik Nona dan menyembunyikannya di sebuah rumah perempuan tua yang jarang dikunjungi orang. Kemudian, Sir Joon mengadu domba ayah Nona dan Tairoo untuk menyamarkan keterlibatannya dalam penculikan Nona. Berkat kecerdikannya, akhirnya Nona dan Sir Joon dapat bersatu. Hal yang menarik adalah kedua orangtua Nona tetap tidak mengetahui bahwa yang menculik anaknya adalah Sir Joon, seperti terlihat dalam kutipan berikut.

Tatkala perempuan tua itu mencium-cium pipi cucunya, maka berkatalah ia dengan tersenyum-senyum,

"Kuharap engkua upik, jika sudah remaja kelak, janganlah senasib dengan ibumu pula, dicuri dan dilarikan orang." Mendengar itu, Sir Joon menunduk dan si Nona menutup mukanya. Dalam beberapa detik itu terkenanglah oleh sepasang kelana itu masa yang sudahsudah, yaitu tiga tahun yang lalu.

(Suman Hs., 2013: 96)

Berdasarkan konflik tersebut, maka dapat disimpulkan bahwa tema dalam novel ini adalah tali percintaan dua orang yang saling mencintai tidak akan putus meskipun orangtua tidak merestui asalkan mereka memperjuangkan cintanya.

Novel terakhir yaitu Dian yang Tak Kunjung Padam (1932) karya S. Takdir Alisjahbana. Novel ini masih berkisah mengenai cinta yang tidak direstui karena perbedaan derajat. Konflik dalam novel ini bermula ketika keluarga Yasin datang ke rumah Molek untuk mempersuntingnya yang kemudian disambut dengan penolakan oleh keluarga Molek karena dianggap tidak setara dengan keluarga Molek yang bangsawan. Molek kemudian hidup menderita dalam perkawinannya dengan Sayid Mustafa karena suaminya tersebut hanya menginginkan harta Molek. Yasin dan Molek tetap saling mencintai meskipun mereka tidak bisa bersatu, yang kemudian disusul dengan kematian Molek akibat sakit yang dideritanya. Sementara itu, gambaran yang diperlihatkan di bagian akhir novel ini yaitu munculnya tokoh Rahman yang 
Vol. 3 No. 1

Juni 2021

e- ISSN 2685 - 0559

p- ISSN 2684 - 673X

melarikan kekasihnya, tersirat bahwa pengarang ingin memberitahu pembaca bahwa kelak generasi mendatang akan dapat mengalahkan golongan tua. Rahman yang melarikan kekasihnya dapat dilihat dalam kutipan berikut.

"Marilah naik dahulu, boleh kita bercakap dengan tenang." Rahman menaiki dua tiga anak tangga, lalu bersandar pada tangga itu. Setelah itu iapun berbisik; ujarnya: "Aku melarikan anak gadis dari dusun Jepara. Mobilku rusak di jalan dan malam ini aku hendak menumpang di rumah mamak."

(Alisjahbana, 2011: 150)

Berdasarkan hal tersebut dapat disimpulkan bahwa tema dalam novel ini adalah percintaan dua anak manusia yang tidak direstui karena perbedaan derajat, namun kelak generasi muda akan dapat mengalahkan generasi tua dengan tidak lagi tunduk pada pemilihan jodoh secara adat.

\section{SIMPULAN}

Berdasarkan hal-hal tersebut di atas dapat disimpulkan bahwa tema-tema-tema dalam periode Balai Pustaka tetap memiliki perbedaan antara satu novel dengan lainnya. Namun, secara umum persoalan yang diangkat dalam novel-novel periode Balai Pustaka memiliki kesamaan, yaitu permasalahan adat, kawin paksa, dan pertentangan antara golongan tua dengan golongan muda sehingga membuat novel-novel tersebut memiliki kesamaan dalam persoalan yang diangkat. Penelitian ini merupakan langkah awal yang baik yang dapat digunakan untuk mendalami isu-isu yang lebih spesifik, misalnya yang berkaitan dengan isu gender, kolonialisme, dan juga ideologi.

\section{REFERENSI}

Alisjahbana, S. Takdir. (2011). Dian yang Tak Kunjung Padam. Jakarta: Penerbit Dian Rakyat.

Hs., Suman. (2013). Mencari Pencuri Anak Perawan. Jakarta: PT. Balai Pustaka.

Moeis, Abdul. (2013). Salah Asuhan. Jakarta: PT. Balai Pustaka.

Ratna, Nyoman Kutha. (2011). Teori, Metode, dan Teknik Penelitian Sastra dari Strukturalisme hingga Postrukturalisme Perspektif Wacana Naratif. Yogyakarta: Pustaka Pelajar.

Rusli, Marah. (2013). Sitti Nurbaya. Jakarta: PT. Balai Pustaka.

Siregar, Merari. (2013). Azab dan Sengsara. Jakarta: PT. Balai Pustaka.

Stanton, Robert. (2012). Teori Fiksi Robert Stanton. Terj. Sugihastuti \& Rossi Abi Al Irsyad. Yogyakarta: Pustaka Pelajar.

Wellek, Rene \& Austin Warren. (2014). Teori Kesusastraan. Terj. Melanie Budianta. Jakarta: Gramedia. 
Vol. 3 No. 1

Juni 2021

e- ISSN 2685 - 0559

p- ISSN 2684 - 673 X
Jurnal

IdeBahasa

Inspirasi Dosen Babasa dan Sastra 